AperTO - Archivio Istituzionale Open Access dell'Università di Torino

Determination of salivary cortisol to assess time related changes of the adrenal response to stress in critically ill patients

This is a pre print version of the following article:

Original Citation:

Availability:

This version is available http://hdl.handle.net/2318/1719506

since $2022-10-12 T 09: 47: 19 Z$

Published version:

DOI:10.1016/j.ejim.2019.08.001

Terms of use:

Open Access

Anyone can freely access the full text of works made available as "Open Access". Works made available under a Creative Commons license can be used according to the terms and conditions of said license. Use of all other works requires consent of the right holder (author or publisher) if not exempted from copyright protection by the applicable law. 
Journal of Internal Medicine

Elsevier Editorial System(tm) for European

Manuscript Draft

Manuscript Number: EJIM-D-19-00637R1

Title: Determination of salivary cortisol to assess time-related changes of the adrenal response to stress in critically ill patients.

Article Type: Original Article

Keywords: serum cortisol; salivary cortisol; critical illness; CIRCI; HPA axis

Corresponding Author: Dr. Soraya Puglisi, MD

Corresponding Author's Institution:

First Author: Soraya Puglisi, MD

Order of Authors: Soraya Puglisi, MD; Andrea Pizzuto, MD; Barbara Laface, MD; Francesco Panero, MD; Franco Aprà, MD; Enrico Palmas, MD; Paola Perotti, BS; Giuseppe Reimondo, MD, PhD; Adriana Boccuzzi, MD; Massimo Terzolo, MD

Abstract: BACKGROUND: The value of salivary cortisol measurement to study stress-related adrenal response is controversial. The study aim was to assess the role of salivary cortisol measurement to detect time-related changes of adrenal response in critically ill patients.

PATIENTS AND METHODS: Patients with organ failure, sepsis or trauma were prospectively recruited in the Emergency Department. Serum and salivary cortisol were measured at baseline (TO) and after 48 hours (T48). In 33 patients ACTH test was also done.

RESULTS: Fifty-five patients were studied and classified as septic (22) or non-septic (33). We found a significant correlation between serum and salivary cortisol at TO and T48. No patient had baseline serum cortisol < $276 \mathrm{nmol} / \mathrm{L}$ and salivary cortisol significantly decreased at T48 in almost all patients. A delta serum cortisol < $250 \mathrm{nmol} / \mathrm{L}$ after ACTH was found in only 4 patients who showed elevated baseline cortisol levels.

CONCLUSION: We found that reduced baseline and post-ACTH cortisol levels are uncommon in our samples. In patients able to provide adequate saliva samples, salivary cortisol may be used to check the degree of stressinduced response and appears as a suitable tool for multiple measurements over time. 
Prof. Giancarlo Agnelli

Editor in Chief of European Journal of Internal Medicine

Dear Prof. Agnelli,

Enclosed you will find the manuscript "DETERMINATION OF SALIVARY CORTISOL TO ASSESS TIME-RELATED CHANGES OF THE ADRENAL RESPONSE TO STRESS IN CRITICALLY ILL PATIENTS" by S. Puglisi et al., which we would like to submit as an Original Article in the European Journal of Internal Medicine.

The mechanisms of adrenal response in critically illness have not yet fully understood and methodological issues related to cortisol measurement provided additional challenges.

In our study, we assessed the role of salivary cortisol measurement to detect time-related changes of adrenal response in critically ill patients.

Currently, the use of salivary cortisol is controversial and we believe that our paper adds novel and interesting information in this area of uncertainty.

Our study demonstrates that in patients able to collaborate salivary cortisol may be used to check the degree of stress-induced activation of the HPA axis, appearing as a suitable tool for multiple measurements over time.

We think that the present findings may be of interest for the readers of European Journal of Internal Medicine.

The authors hereby confirm that neither the manuscript nor any part of it, except for abstracts of less than 400 words, has been published or is being considered for publication elsewhere. By signing this letter each of us acknowledges that he or she participated sufficiently in the work to take public responsibility for its content. The work will not be submitted for publication elsewhere until the editorial board has decided whether to publish the article.

Thank you for considering this manuscript for publication on European Journal of Internal Medicine.

I remain with my best personal regards.

Sincerely yours, 
Author response to reviewer comments

Reviewer comments for: EJIM-D-19-00637

\section{Referee 2}

Comment

This study reports on salivary cortisol concentrations in emergency patients (sepsis vs no sepsis). Indeed, this is a field in which data are controversial. Furthermore, technical problems with salivary cortisol determination exist.

The study is sound, well performed and well presented. Discussion is focused and well tuned. The conclusions are original and supported by the results.

If available, it would be interesting to see also the ACTH concentrations at the time of blood sampling for cortisol as an additional information on the activation of the HPA axis. I understand that given the type of patients and clinical settings, some analyses may not be available and, in any case, ACTH data are not expected to change the conclusions of the study.

Author Response
We would like to thank the Referee for
appreciation of our work.
Regretfully, the assessment of plasma ACTH
was not part of the design of the study.

Therefore, values of ACTH concentrations are not available.
Text Insertion (if applicable)/ page/ line number of change

n/a




\section{DETERMINATION OF SALIVARY CORTISOL TO ASSESS TIME- RELATED CHANGES OF THE ADRENAL RESPONSE TO STRESS IN CRITICALLY ILL PATIENTS.}

Soraya Puglisi ${ }^{1 *}$, Andrea Pizzuto ${ }^{2}$, Barbara Laface ${ }^{3}$, Francesco Panero $^{3}$, Franco Aprà ${ }^{3}$, Enrico Palmas $^{4}$, Paola Perotti ${ }^{1}$, Giuseppe Reimondo ${ }^{1}$, Adriana Boccuzzi ${ }^{5}$, Massimo Terzolo ${ }^{1}$. *SP and AP have equally contributed to the study.

${ }^{1}$ Internal Medicine 1, Department of Clinical and Biological Sciences, University of Turin, Italy;

${ }^{2}$ Internal Medicine 2 U, A.O.U Citta della Salute e della Scienza, Department of Clinical and Biological Sciences, University of Turin, Italy

${ }^{3}$ Emergency Medicine, A.O. San Giovanni Bosco Hospital, Turin, Italy

${ }^{4}$ Emergency Medicine, Azienda Sanitaria Universitaria Integrata of Udine, Italy

${ }^{5}$ Emergency Medicine, A.O.U San Luigi Hospital, Orbassano (Turin), Italy

Corresponding Author: Soraya Puglisi

Internal Medicine 1, Department of Clinical and Biological Sciences, San Luigi Gonzaga Hospital, Regione Gonzole 10, 10043 Orbassano, Italy; tel: +39 011 9026292, fax: +39 0116705456

e-mail: sorayapuglisi@yahoo.it

KEY WORDS: serum cortisol, salivary cortisol, critical illness, CIRCI, HPA axis 


\begin{abstract}
:
BACKGROUND: The value of salivary cortisol measurement to study stress-related adrenal response is controversial. The study aim was to assess the role of salivary cortisol measurement to detect time-related changes of adrenal response in critically ill patients.
\end{abstract}

PATIENTS AND METHODS: Patients with organ failure, sepsis or trauma were prospectively recruited in the Emergency Department. Serum and salivary cortisol were measured at baseline (T0) and after 48 hours (T48). In 33 patients ACTH test was also done.

RESULTS: Fifty-five patients were studied and classified as septic (22) or non-septic (33). We found a significant correlation between serum and salivary cortisol at T0 and T48. No patient had baseline serum cortisol $<276 \mathrm{nmol} / \mathrm{L}$ and salivary cortisol significantly decreased at $\mathrm{T} 48$ in almost all patients. A delta serum cortisol $<250 \mathrm{nmol} / \mathrm{L}$ after ACTH was found in only 4 patients who showed elevated baseline cortisol levels.

CONCLUSION: We found that reduced baseline and post-ACTH cortisol levels are uncommon in our samples. In patients able to provide adequate saliva samples, salivary cortisol may be used to check the degree of stress-induced response and appears as a suitable tool for multiple measurements over time. 


\section{INTRODUCTION}

The physiological response to acute stress and life-threatening conditions includes an increased activity of the adrenal glands resulting in raised cortisol levels, which are needed to support vital functions and restore homeostasis (fight or flight response) [1]. Studies pointed out that inadequate cortisol response to stressful stimuli might be associated with increased risk of mortality [2,3]. Therefore, the concept of "critical illness-related corticosteroid insufficiency" (CIRCI) has been introduced to define a condition characterized by baseline cortisol levels $<276 \mathrm{nmol} / \mathrm{L}$ or delta cortisol (difference between peak and baseline cortisol levels during a $250 \mu \mathrm{g}$ ACTH stimulation test) $<250 \mathrm{nmol} / \mathrm{L}$ [4], although these criteria are still debated [5]. More recently, studies challenged this concept showing that high cortisol levels in critically ill patients were actually associated with increased risk of mortality $[6,7,8]$. In this area of uncertainty there is a further difficulty due to methodological issues related to cortisol measurement, because in acutely ill patients albumin and cortisol-binding protein (CBG) levels may be altered and a standardized method to evaluate free plasma cortisol is not currently available [9]. Although some evidence suggest that salivary cortisol could be a surrogate marker for serum free cortisol $[10,11,12,13,14]$ data are lacking to support its routine use in critically ill patients [4].

Therefore, the aim of the present study was to determine cortisol levels in a population of critically ill patients in the first 48 hours after their admission in the Emergency Room, and to test if salivary cortisol measurement may add useful information to serum cortisol measurement. 


\section{PATIENTS AND METHODS}

\section{Patients}

Patients were prospectively recruited in the Emergency Department of the San Giovanni Bosco Hospital (Turin), among those subsequently admitted in the Emergency Medical Unit, from September 2016 to December 2017. The study was conducted in accordance with the ethical guidelines of the 2003 (Declaration of Helsinki) and approved by the San Giovanni Bosco Hospital Ethics Committee. Written consent was obtained from patients and/or their designated family members.

Critically ill patients affected by a wide range of illness, and displaying single or multiple organ failure, were enrolled on the basis of the following inclusion and exclusion criteria. Inclusion criteria were: one or more of the followings: acute respiratory insufficiency, cardiovascular insufficiency or other organ insufficiency, sepsis or septic shock, acute pancreatitis, trauma (no brain injury), post-surgical complications. Diagnosis of sepsis and septic shock were based on the criteria established by the American College of Chest Physicians and the Society of Critical Care Medicine [15]. Exclusion criteria were: age $<18$ years, ongoing mechanical ventilation, current or recent glucocorticoid therapy, neoplastic disease, intake of drugs known to influence glucocorticoids secretion (etomidate, ketoconazole, estrogen, phenytoin, phenobarbital and rifampicin), known pituitary, adrenal or liver disease, HIV or mycobacterial infection, pregnancy, immunosuppressive therapy. Patients were enrolled at the Emergency Room (ER) before admission. Assessment of the hypothalamic pituitary axis (HPA) was done at patient enrollment (T0) and after 48 hours (T48), in concomitance with physical exam and routine biochemical evaluation. The severity of illness was assessed by the Simplified Acute Physiology Score (SAPS) II and qSOFA score [16]. The life status (death/alive) of the patients was checked at T48 and at day 28 after admission. 


\section{Methods}

Within 24 hours from admission, blood and saliva samples were concomitantly obtained from all patients (baseline, T0). Blood and saliva samples were also taken after 48 hours (T48) from the first samples. Saliva samples were obtained by giving patients three cotton swabs to chew for 2 minutes. The cotton swabs were then placed in a saliva-collecting device (Salivette ${ }^{\circledR}-$ Sarstedt, Numbrecht, Germany) and centrifuged at $3000 \mathrm{rpm}$ for $15 \mathrm{~min}$. The cotton swabs were removed, and the samples were frozen at $-20{ }^{\circ} \mathrm{C}$ until assayed. At baseline, salivary cortisol and serum cortisol were measured. At T48, salivary and serum cortisol were measured. Routine laboratory measurements included arterial blood gases, lactate, C-reactive protein, procalcitonin, blood electrolytes, total blood cells count, liver function tests, creatinine, and albumin.

Immediately after baseline sampling, 33 patients underwent a short corticotropin stimulation test. This test was performed between h.08.00 and 9.00 a.m. by intravenous administration of $250 \mu \mathrm{g}$ of synthetic corticotropin (tetra-cosactide-hexa-acetate, Synacthen, Novartis Pharma, Basel, Switzerland). Blood and salivary samples were taken immediately before and 60 minutes after ACTH injection. The difference between serum cortisol at $60 \mathrm{~min}$ and at baseline (delta cortisol) was calculated to assess the response to ACTH stimulation. A subnormal response to ACTH stimulation was defined by a delta cortisol $<250 \mathrm{nmol} / \mathrm{L}[4]$.

\section{Laboratory analyses}

Salivary cortisol concentrations were determined using an ELISA kit (Enzyme-Linked ImmunoSorbent Assay), obtained from DGR instruments GmbH (Germany). The assay sensitivity was $1 \mathrm{nmol} / \mathrm{L}$. As to specificity, this cortisol assay does not show cross-reaction with cortisone, deoxycorticosterone, 11-deoxycorticortisol, estradiol, testosterone, and 17-hydroxyprogesterone, while it cross-reacts $29 \%$ with corticosterone and $3 \%$ with cortisone. The reference range for our laboratory was 3-40 nmol/L, for both sexes. 
Serum cortisol was measured by chemiluminescent immunometric assay (Immulite 1000, Siemens

Medical Solutions Diagnostics, Los Angeles, CA, USA). The detection limit was $5 \mathrm{nmol} / \mathrm{L}$. The reference range was $250-690 \mathrm{nmol} / \mathrm{L}$.

\section{Statistical analyses}

All statistical analyses were performed with STATA statistical software. Categorical data were presented as rates and proportions, continuous data as medians and ranges. Wilcoxon rank-sum test was used for analysis of continuous variables and Chi-Square Test was used for nominal or ordinal explanatory and response variables. $\mathrm{P}$ values of less than 0.05 were considered to indicate statistical significance. 


\section{RESULTS}

A total of 71 patients were eligible for inclusion in the study. One patient was excluded because he received a steroid pulse before admission and 15 patients were excluded because the amount of saliva samples was insufficient for the assay (Figure 1).

Baseline characteristics of the 55 evaluated patients are reported in Table 1.

Table 1. Baseline features of the overall samples and the two groups classified according to presence of sepsis.

\begin{tabular}{|c|c|c|c|c|}
\hline Characteristics & $\begin{array}{c}\text { Overall } \\
(\mathbf{n}=55)\end{array}$ & $\begin{array}{l}\text { Sepsis } \\
(\mathrm{n}=22)\end{array}$ & $\begin{array}{l}\text { No Sepsis } \\
\quad(\mathbf{n}=\mathbf{3 3})\end{array}$ & $p$ \\
\hline $\begin{array}{l}\text { Gender }- \text { N. (\%) } \\
\text { Male } \\
\text { Female }\end{array}$ & $\begin{array}{l}36(65 \%) \\
19(35 \%)\end{array}$ & $\begin{array}{c}14(63.6 \%) \\
8(36.4 \%)\end{array}$ & $\begin{array}{l}22(66.7 \%) \\
11(33.3 \%)\end{array}$ & 0.86 \\
\hline $\begin{array}{l}\text { Age at admission - yr } \\
\text { Median [range] }\end{array}$ & 70 [17-87] & 65 [42-87] & 71 [17-84] & 0.49 \\
\hline $\begin{array}{l}\text { BMI }-\mathrm{kg} / \mathrm{m}^{2} \\
\text { Median } \\
\text { [range] }\end{array}$ & $\begin{array}{c}26.8 \\
{[16.3-48.9]}\end{array}$ & $\begin{array}{c}26.0 \\
{[16.3-46.8]}\end{array}$ & $\begin{array}{c}27.5 \\
{[18.5-48.9]}\end{array}$ & 0.10 \\
\hline $\begin{array}{l}\text { Systolic Blood Pressure - } \\
\text { (mmHg) } \\
\text { Median [range] }\end{array}$ & 130 [70-230] & 125 [70-230] & 136 [87-230] & 0.07 \\
\hline $\begin{array}{l}\text { Diastolic Blood Pressure - } \\
\text { (mmHg) } \\
\text { Median [range] }\end{array}$ & 70 [35-130] & 70 [40-130] & 70 [35-120] & 0.47 \\
\hline $\begin{array}{l}\text { Heart rate }-(\mathrm{bpm}) \\
\text { Median [range] }\end{array}$ & 90 [65-160] & 99 [70-130] & 86 [65-160] & 0.32 \\
\hline $\begin{array}{l}\text { Respiratory rate - (bpm) } \\
\text { Median [range] }\end{array}$ & 26 [12-46] & 24 [12-46] & 27 [14-44] & 0.93 \\
\hline $\begin{array}{l}\mathbf{S O}_{2}-(\%) \\
\text { Median [range] }\end{array}$ & 94 [70-99] & 96 [70-99] & 94 [72-99] & 0.91 \\
\hline $\begin{array}{l}\text { Temperature }-\left({ }^{\circ} \mathrm{C}\right) \\
\text { Median [range] }\end{array}$ & 37 [36-41] & $37.4[36-41]$ & 37 [36-39] & 0.01 \\
\hline $\begin{array}{l}\text { Lactate }-(\mathrm{mmol} / \mathrm{L}) \\
\text { Median [range] }\end{array}$ & $1.4[0.1-8.3]$ & $1.5[0.5-7.7]$ & $1.4[0.1-8.3]$ & 0.80 \\
\hline
\end{tabular}




\begin{tabular}{|l|c|c|c|c|}
\hline $\begin{array}{l}\text { Protein - (g/dL) } \\
\text { Median [range] }\end{array}$ & $6.1[4.3-7.9]$ & $5.5[4.3-7.8]$ & $6.3[5.5-7.1]$ & $\mathbf{0 . 0 2}$ \\
\hline $\begin{array}{l}\text { Albumin - (g/dL) } \\
\text { Median [range] }\end{array}$ & $3.1[0.5-4.3]$ & $2.8[1.5-4.3]$ & $3.4[0.5-4.3]$ & $\mathbf{0 . 0 2}$ \\
\hline $\begin{array}{l}\text { Hospitalization - (day) } \\
\text { Median [range] }\end{array}$ & $11[4-38]$ & $11[4-24]$ & $10.5[4-38]$ & 0.73 \\
\hline $\begin{array}{l}\text { Hospitalization in ED- (day) } \\
\text { Median [range] }\end{array}$ & $6[1-21]$ & $6[2-15]$ & $5[1-10]$ & 0.76 \\
\hline
\end{tabular}

BMI=body mass index; $\mathrm{SBP}=$ =systolic blood pressure; DBP=diastolic blood pressure; $\mathrm{SO2}=$ hemoglobin oxygen saturation.

The patient group had different medical emergencies; the most frequent diagnosis at presentation was acute respiratory failure $(50.9 \%)$ followed by acute heart failure $(16.4 \%)$, suspected infections $(16.4 \%)$, trauma $(7.3 \%)$, acute pancreatitis $(3.6 \%)$, septic shock $(3.6 \%)$, or any organ failure $(1.8 \%)$. A broad spectrum of comorbidities affected our patients, such as arterial hypertension (56.4\%), diabetes mellitus (30.9\%), coronary artery disease (25.4\%), heart failure (21.8\%), chronic kidney disease (20\%), chronic obstructive pulmonary disease (20\%), arrhythmia (14.5\%), vascular disease (7.3\%), liver disease (3.6\%), pulmonary hypertension (3.6\%), peripheral arterial disease (1.8\%), peptic ulcer $(1.8 \%)$, autoimmune diseases $(1.8 \%)$. We divided our population in two subgroups based on the presence of sepsis, which was diagnosed in 22 out of 55 patients. Baseline characteristics of the two subgroups of patients are reported in Table $\mathbf{1 .}$

In the overall sample, the median SAPS II score was 37 (16-77), without difference between the two groups (sepsis group, 36, 16-61 vs. no-sepsis group, 37, 17-77, $p=0.76$ ). In the sepsis group, the median qSOFA was 1 [range 0-2].

Median serum cortisol concentration at T0 in the overall sample was $819 \mathrm{nmol} / \mathrm{L}$ (292-2458 $\mathrm{nmol} / \mathrm{L}$ ) and median salivary cortisol concentration at T0 was $41 \mathrm{nmol} / \mathrm{L}$ (range $1-347 \mathrm{nmol} / \mathrm{L}$ ). No patient had baseline serum cortisol $<276 \mathrm{nmol} / \mathrm{L}$. Median serum cortisol concentration at T48 was $634 \mathrm{nmol} / \mathrm{L}(287-1826 \mathrm{nmol} / \mathrm{L})$ and median salivary cortisol concentration at T48 was $13 \mathrm{nmol} / \mathrm{L}$ 
(range 1-253 nmol/L). We found a significant correlation between serum and salivary cortisol concentrations measured at T0 $(r 0.84, p<0.001)$, and T48 $(r 0.81, p<0.001)$.

We found a statistically significant difference between salivary cortisol concentrations at T0 vs. T48 ( $p<0.001)$ (Figure 2).

In the sepsis group, salivary cortisol concentration decreased from $60 \mathrm{nmol} / \mathrm{L}$ (range $1-347 \mathrm{nmol} / \mathrm{L}$ ) at T0 to $21 \mathrm{nmol} / \mathrm{L}(1-135 \mathrm{nmol} / \mathrm{L})$ at T48 $(p<0.001)$. In the no-sepsis group, salivary cortisol concentration decreased from $39 \mathrm{nmol} / \mathrm{L}$ (range $1-221 \mathrm{nmol} / \mathrm{L}$ ) at T0 to $11 \mathrm{nmol}$ (range 1-253 $\mathrm{nmol} / \mathrm{L})$ at T48 ( $p=0.022)$ (Figure 3). We also compared salivary cortisol concentrations between the two groups and we found a statistically significant difference in salivary cortisol values at T48 $(p=0.03)$, while no significant difference was apparent at T0 (Figure 3).

We did not find any significant correlation between serum or salivary cortisol and SAPS values.

For logistic reasons (i.e. night-time admission), the ACTH stimulation test was performed in 33 patients. The serum cortisol value at $60 \mathrm{~min}$ was $1534 \mathrm{nmol} / \mathrm{L}(510-2676 \mathrm{nmol} / \mathrm{L})$, and the salivary cortisol was $156 \mathrm{nmol} / \mathrm{L}$ (range 17-1528 nmol/L); with a significant correlation between them $(r$ $0.49, p<0.01$ ). The delta serum cortisol was $588 \mathrm{nmol} / \mathrm{L}$ (range $-110-1432 \mathrm{nmol} / \mathrm{L}$ ) and the percentage of the increase was $79 \%$ (range $-6-393 \%$ ). The delta salivary cortisol was $113 \mathrm{nmol} / \mathrm{L}$ (range $-54-1308 \mathrm{nmol} / \mathrm{L}$ ) and the percentage of the increase was 191\% (range $-16-1672 \%$ )

\section{(Figure 4).}

We found a delta serum cortisol $<250 \mathrm{nmol} / \mathrm{L}$ in 4 out 33 cases $(12.1 \%)$. These patients had exceedingly high serum cortisol levels at T0 (1581; 1545; 2458; $1975 \mathrm{nmol} / \mathrm{L}$, respectively), high values of SAPS $(39,58,61,77$, respectively), increased lactate concentrations, and sepsis was diagnosed in three of them. The response of salivary cortisol to Synacthen was also blunted (percent of increment $37 \%,-7 \%,-16 \%, 18 \%$, respectively).

Mortality rate was $1 / 55$ patients at $\mathrm{T} 48$, and $5 / 55$ patients at day 28 . Due to the low mortality rate observed in our cohort, we did not analyze the correlation with cortisol levels. 


\section{DISCUSSION}

In the last 30 years, there was a fierce debate on the existence of a correlation between mortality and cortisol levels in critically ill patients, particularly when levels are at the lower end of the spectrum, configuring the so-called CIRCI $[2,4,5]$, or when they are exceedingly high $[6,7,8]$. In both cases, the assessment of serum cortisol is not completely reliable, due to the decrease of CBG and albumin in critically ill patients [17]. As a matter of fact, $80-90 \%$ of serum cortisol is bound to CBG, $5-10 \%$ is bound to albumin, while only $5 \%$ is unbound [18]. At the same time, the laboratory evaluation of free serum cortisol is difficult, requiring special equipment. On the contrary, salivary cortisol measurement is cheap, noninvasive and unaffected by variations in CBG or albumin.

The recent guidelines on CIRCI diagnosis and management suggest against the use of salivary cortisol for diagnostic purposes, although this is a conditional recommendation with a very low quality of evidence [5]. One of the objections raised in the guidelines concerns the difficulty in collecting adequate salivary samples in critically ill patients, often intubated and dehydrated. Studies report that it was impossible to analyze about $30 \%$ of the salivary samples, due to insufficient saliva, or blood contamination [13,14]; conversely, in one study [12] only $5.5 \%$ of enrolled patients had inadequate saliva samples. In the present study, we confirm that collecting saliva is not an easy task in the ER, since $21.4 \%$ of our patients were excluded due to a small volume of saliva collected. This discrepancy among the studies is probably due to different types of population analyzed, with variable grade of illness severity and number of intubated patients. Whether the use of different saliva-collecting devices (for example infant-swab-devices) could ameliorate the success of obtaining adequate saliva samples in critically ill patients deserves future investigation.

Many studies supported the use of salivary cortisol as a surrogate for free cortisol in patients with critical illness, because it is as reliable as serum free cortisol, but not affected by the high cost and low availability of equilibrium dialysis, needed to determine free serum cortisol $[12,13,14]$. This concept was confirmed by our study, where we found a significant correlation between serum 
and salivary cortisol measurements. The strong correlation between salivary cortisol and total serum

cortisol levels has been demonstrated not only at baseline, as in previous studies $[12,13,14]$ but also after 48 hours of hospitalization. This is a new element introduced by our research reporting a statistically significant difference between T0 and T48 salivary cortisol concentrations in the whole group, and in the two subgroups of septic and non-septic patients. We showed that salivary cortisol decreases after 48 hours, a finding that likely reflects the shutting down of adrenal hyperactivity. Interestingly, the change in salivary cortisol seems to be more sensitive and precocious that serum cortisol, which was less modified over time. We observed a similar pattern during ACTH stimulation test. There are scanty data on the response of salivary cortisol to Synacthen and a universally accepted cut-off is not available $[12,19,20]$, due to the great heterogeneity of the assays used to measure salivary cortisol between different studies.

This is the first study with a direct comparison between septic and non-septic patients, classified on the basis of the recent diagnostic criteria of sepsis [16]. In our study, we did not find any correlation between the severity of illness and salivary or serum cortisol levels. Therefore, our data do not seem to support the hypothesis that salivary cortisol increases in parallel to the severity of stress [13]. However, we may disclose the fact that the severity of illness and sepsis was moderate in many patients. Moreover, we found a significantly higher value of salivary cortisol at T48 in the group of septic patients, which may reflect a more persistent activation of the HPA axis in this condition. We also found a correlation between serum and salivary cortisol at 60 min of the ACTH stimulation test. The role of salivary cortisol as surrogate for serum free cortisol in dynamic testing of adrenocortical function has been previously investigated $[12,19,20]$, and our findings further support the use of salivary cortisol in this setting.

We did not find any evidence of CIRCI in our cohort, since no patient had baseline serum cortisol $<276 \mathrm{nmol} / \mathrm{L}$, and a delta serum cortisol $<250 \mathrm{nmol} / \mathrm{L}$ after ACTH stimulation was observed in only $12 \%$ of cases. However, baseline cortisol levels were very high in such patients, suggesting that the reduced delta cortisol value may reflect a maximally stimulated HPA axis more than 
adrenal insufficiency. Interestingly, the 4 patients with a delta serum cortisol $<250 \mathrm{nmol} / \mathrm{L}$ after ACTH stimulation had concomitantly blunted salivary cortisol response.

We acknowledge the limitations of the study, including a small sample size and the heterogeneity of the population. Moreover, it could be argued that the low severity of illness in our patients, confirmed by a low mortality rate, is also a limitation.

To conclude, proven that patients are able to collaborate and provide adequate saliva samples, salivary cortisol may be used to check the degree of stress-induced activation of the HPA axis, and appears as a suitable tool for multiple measurements over time.

\section{Declaration of Interest:}

The authors have stated explicitly that there are no conflicts of interest in connection with this article.

Funding: This research did not receive any specific grant from any funding agency in the public, commercial or not-for-profit sector.

Acknowledgements: We wish to thank Laura Saba for assistance with lab assays. 


\section{REFERENCES}

(1) Chrousos, G. P. Stress and Disorders of the Stress System. Nature Reviews Endocrinology 2009, 5 (7), 374-381. https://doi.org/10.1038/nrendo.2009.106.

(2) Annane, D.; Sébille, V.; Troché, G.; Raphaël, J. C.; Gajdos, P.; Bellissant, E. A 3-Level Prognostic Classification in Septic Shock Based on Cortisol Levels and Cortisol Response to Corticotropin. JAMA : the journal of the American Medical Association 2000, 283 (8), 1038-1045. https://doi.org/10.1001/jama.283.8.1038.

(3) Schroeder, S.; Wichers, M.; Klingmüller, D.; Höfer, M.; Lehmann, L. E.; von Spiegel, T.; Hering, R.; Putensen, C.; Hoeft, A.; Stüber, F. The Hypothalamic-Pituitary-Adrenal Axis of Patients with Severe Sepsis: Altered Response to Corticotropin-Releasing Hormone. Critical care medicine 2001, 29 (2), 310-316.

(4) Marik, P. E.; Pastores, S. M.; Annane, D.; Meduri, G. U.; Sprung, C. L.; Arlt, W.; Keh, D.; Briegel, J.; Beishuizen, A.; Dimopoulou, I.; et al. Recommendations for the Diagnosis and Management of Corticosteroid Insufficiency in Critically III Adult Patients: Consensus Statements from an International Task Force by the American College of Critical Care Medicine. Crit Care Med 2008, 36 (6), 1937-1949. https://doi.org/10.1097/CCM.0b013e31817603ba.

(5) Annane, D.; Pastores, S. M.; Rochwerg, B.; Arlt, W.; Balk, R. A.; Beishuizen, A.; Briegel, J.; Carcillo, J.; Christ-Crain, M.; Cooper, M. S.; et al. Guidelines for the Diagnosis and Management of Critical Illness-Related Corticosteroid Insufficiency (CIRCI) in Critically III Patients (Part I): Society of Critical Care Medicine (SCCM) and European Society of Intensive Care Medicine (ESICM) 2017. Critical care medicine 2017, 45 (12), 2078-2088. https://doi.org/10.1097/CCM.0000000000002737.

(6) Tarjanyi, Z.; Montsko, G.; Kenyeres, P.; Marton, Z.; Hagendorn, R.; Gulyas, E.; Nemes, O.; Bajnok, L.; G, L. K.; Mezosi, E. Free and Total Cortisol Levels Are Useful Prognostic Markers in Critically III Patients: A Prospective Observational Study; 2014; Vol. 171. https://doi.org/10.1530/EJE-14-0576.

(7) Levy-Shraga, Y.; Pinhas-Hamiel, O.; Molina-Hazan, V.; Tamir-Hostovsky, L.; Eini, Z. M.; Lerner-Geva, L.; Paret, G. Elevated Baseline Cortisol Levels Are Predictive of Bad Outcomes in Critically III Children. Pediatric emergency care 2018, 34 (9), 613-617. https://doi.org/10.1097/PEC.0000000000000784.

(8) Pandya, U.; Polite, N.; Wood, T.; Lieber, M. Increased Total Serum Random Cortisol Levels Predict Mortality in Critically III Trauma Patients.

(9) Arafah, B. M. Hypothalamic Pituitary Adrenal Function during Critical Illness: Limitations of Current Assessment Methods. The Journal of clinical endocrinology and metabolism 2006, 91 (10), 37253745. https://doi.org/10.1210/jc.2006-0674.

(10) Gozansky, W. S.; Lynn, J. S.; Laudenslager, M. L.; Kohrt, W. M. Salivary Cortisol Determined by Enzyme Immunoassay is Preferable to Serum Total Cortisol for Assessment of Dynamic Hypothalamic-Pituitary-Adrenal Axis Activity. Clinical Endocrinology 2005, 63 (3), 336-341. https://doi.org/10.1111/j.1365-2265.2005.02349.x.

(11) Raff, H. Utility of Salivary Cortisol Measurements in Cushing's Syndrome and Adrenal Insufficiency. Journal of Clinical Endocrinology and Metabolism 2009, 94 (10), 3647-3655. https://doi.org/10.1210/jc.2009-1166.

(12) Arafah, B. M.; Nishiyama, F. J.; Tlaygeh, H.; Hejal, R. Measurement of Salivary Cortisol Concentration in the Assessment of Adrenal Function in Critically III Subjects: A Surrogate Marker of the Circulating Free Cortisol. Journal of Clinical Endocrinology and Metabolism 2007, 92 (8), 2965-2971. https://doi.org/10.1210/jc.2007-0181.

(13) Carvalho, R.; De Mello, V.; Sad, E. F.; Andrade, B. C.; Pretti, S.; Neves, F.; Maria, S.; Santos, E.; Maria, M.; Sarquis, S.; et al. Serum and Salivary Cortisol in the Diagnosis of Adrenal Insufficiency and as a Predictor of the Outcome in Patients with Severe Sepsis. Arq Bras Endocrinol Metab 2011, 5555 (77), 455-459. https://doi.org/10.1590/S0004-27302011000700004.

(14) Estrada-Y-Martin, R. M.; Orlander, P. R. Salivary Cortisol Can Replace Free Serum Cortisol Measurements in Patients with Septic Shock. Chest 2011, 140 (5), 1216-1222. https://doi.org/10.1378/chest.11-0448. 
(15) Singer, M.; Deutschman, C. S.; Seymour, C. W.; Shankar-Hari, M.; Annane, D.; Bauer, M.; Bellomo, R.; Bernard, G. R.; Chiche, J.-D.; Coopersmith, C. M.; et al. The Third International Consensus Definitions for Sepsis and Septic Shock (Sepsis-3). Jama 2016, 315 (8), 801-810.

https://doi.org/10.1001/jama.2016.0287.

(16) Le Gall, J.-R.; Lemeshow, S.; Saulnier, F. A New Simplified Acute Physiology Score (SAPS II) Based on a European/North American Multicenter Study. JAMA: The Journal of the American Medical Association 1993, 270 (24), 2957. https://doi.org/10.1001/jama.1993.03510240069035.

(17) Beishuizen, A.; Thijs, L. G.; Vermes, I. Patterns of Corticosteroid-Binding Globulin and the Free Cortisol Index during Septic Shock and Multitrauma. Intensive Care Medicine 2001, 27 (10), 15841591. https://doi.org/10.1007/s001340101073.

(18) Hammond, G. L.; Smith, C. L.; Underhill, D. A. Molecular Studies of Corticosteroid Binding Globulin Structure, Biosynthesis and Function. The Journal of Steroid Biochemistry and Molecular Biology 1991, 40 (4-6), 755-762. https://doi.org/10.1016/0960-0760(91)90300-T.

(19) Raff, H.; Biru, N.; Reisinger, N., Kramer, D.J. Dissociation of ACTH and cortisol in septic and nonseptic ICU patients. Endocrine. 2017, 55 (1), 307-310. https://doi.org/10.1007/s12020 016-1034-2.

(20) Raff, H.; Brock, S.; Findling, JW. Cosyntropin-stimulated salivary cortisol in hospitalized patients with hypoproteinemia. Endocrine. 2008, 34 (1-3), 68-74. https://doi.org/10.1007/s12020-008-9101-y. 


\section{DETERMINATION OF SALIVARY CORTISOL TO ASSESS TIME- RELATED CHANGES OF THE ADRENAL RESPONSE TO STRESS IN CRITICALLY ILL PATIENTS.}

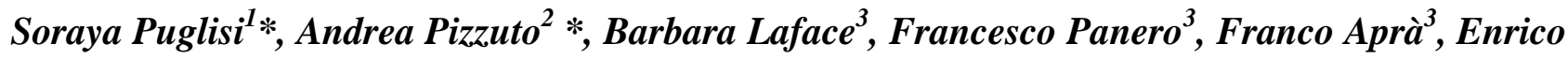
Palmas $^{4}$, Paola Perotti ${ }^{1}$, Giuseppe Reimondo ${ }^{1}$, Adriana Boccuzzi ${ }^{5}$, Massimo Terzolo ${ }^{1}$. *SP and AP have equally contributed to the study.

${ }^{1}$ Internal Medicine 1, Department of Clinical and Biological Sciences, University of Turin, Italy;

${ }^{2}$ Internal Medicine 2 U, A.O.U Citta della Salute e della Scienza, Department of Clinical and Biological Sciences, University of Turin, Italy

${ }^{3}$ Emergency Medicine, A.O. San Giovanni Bosco Hospital, Turin, Italy

${ }^{4}$ Emergency Medicine, Azienda Sanitaria Universitaria Integrata of Udine, Italy

${ }^{5}$ Emergency Medicine, A.O.U San Luigi Hospital, Orbassano (Turin), Italy

Corresponding Author: Soraya Puglisi

Internal Medicine 1, Department of Clinical and Biological Sciences, San Luigi Gonzaga Hospital, Regione Gonzole 10, 10043 Orbassano, Italy; tel: +39 011 9026292, fax: +39 0116705456

e-mail: sorayapuglisi@yahoo.it

KEY WORDS: serum cortisol, salivary cortisol, critical illness, CIRCI, HPA axis 


\section{ABSTRACT:}

BACKGROUND: The value of salivary cortisol measurement to study stress-related adrenal response is controversial. The study aim was to assess the role of salivary cortisol measurement to detect time-related changes of adrenal response in critically ill patients.

PATIENTS AND METHODS: Patients with organ failure, sepsis or trauma were prospectively recruited in the Emergency Department. Serum and salivary cortisol were measured at baseline (T0) and after 48 hours (T48). In 33 patients ACTH test was also done.

RESULTS: Fifty-five patients were studied and classified as septic (22) or non-septic (33). We found a significant correlation between serum and salivary cortisol at T0 and T48. No patient had baseline serum cortisol $<276 \mathrm{nmol} / \mathrm{L}$ and salivary cortisol significantly decreased at T48 in almost all patients. A delta serum cortisol $<250 \mathrm{nmol} / \mathrm{L}$ after ACTH was found in only 4 patients who showed elevated baseline cortisol levels.

CONCLUSION: We found that reduced baseline and post-ACTH cortisol levels are uncommon in our samples. In patients able to provide adequate saliva samples, salivary cortisol may be used to check the degree of stress-induced response and appears as a suitable tool for multiple measurements over time. 


\section{INTRODUCTION}

The physiological response to acute stress and life-threatening conditions includes an increased activity of the adrenal glands resulting in raised cortisol levels, which are needed to support vital functions and restore homeostasis (fight or flight response) [1]. Studies pointed out that inadequate cortisol response to stressful stimuli might be associated with increased risk of mortality $[2,3]$. Therefore, the concept of "critical illness-related corticosteroid insufficiency" (CIRCI) has been introduced to define a condition characterized by baseline cortisol levels $<276 \mathrm{nmol} / \mathrm{L}$ or delta cortisol (difference between peak and baseline cortisol levels during a $250 \mu \mathrm{g}$ ACTH stimulation test $)<250 \mathrm{nmol} / \mathrm{L}$ [4], although these criteria are still debated [5]. More recently, studies challenged this concept showing that high cortisol levels in critically ill patients were actually associated with increased risk of mortality $[6,7,8]$. In this area of uncertainty there is a further difficulty due to methodological issues related to cortisol measurement, because in acutely ill patients albumin and cortisol-binding protein (CBG) levels may be altered and a standardized method to evaluate free plasma cortisol is not currently available [9]. Although some evidence suggest that salivary cortisol could be a surrogate marker for serum free cortisol $[10,11,12,13,14]$ data are lacking to support its routine use in critically ill patients [4].

Therefore, the aim of the present study was to determine cortisol levels in a population of critically ill patients in the first 48 hours after their admission in the Emergency Room, and to test if salivary cortisol measurement may add useful information to serum cortisol measurement. 


\section{PATIENTS AND METHODS}

\section{Patients}

Patients were prospectively recruited in the Emergency Department of the San Giovanni Bosco Hospital (Turin), among those subsequently admitted in the Emergency Medical Unit, from September 2016 to December 2017. The study was conducted in accordance with the ethical guidelines of the 2003 (Declaration of Helsinki) and approved by the San Giovanni Bosco Hospital Ethics Committee. Written consent was obtained from patients and/or their designated family members.

Critically ill patients affected by a wide range of illness, and displaying single or multiple organ failure, were enrolled on the basis of the following inclusion and exclusion criteria. Inclusion criteria were: one or more of the followings: acute respiratory insufficiency, cardiovascular insufficiency or other organ insufficiency, sepsis or septic shock, acute pancreatitis, trauma (no brain injury), post-surgical complications. Diagnosis of sepsis and septic shock were based on the criteria established by the American College of Chest Physicians and the Society of Critical Care Medicine [15]. Exclusion criteria were: age $<18$ years, ongoing mechanical ventilation, current or recent glucocorticoid therapy, neoplastic disease, intake of drugs known to influence glucocorticoids secretion (etomidate, ketoconazole, estrogen, phenytoin, phenobarbital and rifampicin), known pituitary, adrenal or liver disease, HIV or mycobacterial infection, pregnancy, immunosuppressive therapy. Patients were enrolled at the Emergency Room (ER) before admission. Assessment of the hypothalamic pituitary axis (HPA) was done at patient enrollment (T0) and after 48 hours (T48), in concomitance with physical exam and routine biochemical evaluation. The severity of illness was assessed by the Simplified Acute Physiology Score (SAPS) II and qSOFA score [16]. The life status (death/alive) of the patients was checked at T48 and at day 28 after admission. 


\section{Methods}

Within 24 hours from admission, blood and saliva samples were concomitantly obtained from all patients (baseline, T0). Blood and saliva samples were also taken after 48 hours (T48) from the first samples. Saliva samples were obtained by giving patients three cotton swabs to chew for 2 minutes. The cotton swabs were then placed in a saliva-collecting device (Salivette ${ }^{\circledR}-$ Sarstedt, Numbrecht, Germany) and centrifuged at $3000 \mathrm{rpm}$ for $15 \mathrm{~min}$. The cotton swabs were removed, and the samples were frozen at $-20{ }^{\circ} \mathrm{C}$ until assayed. At baseline, salivary cortisol and serum cortisol were measured. At T48, salivary and serum cortisol were measured. Routine laboratory measurements included arterial blood gases, lactate, C-reactive protein, procalcitonin, blood electrolytes, total blood cells count, liver function tests, creatinine, and albumin.

Immediately after baseline sampling, 33 patients underwent a short corticotropin stimulation test. This test was performed between h.08.00 and 9.00 a.m. by intravenous administration of $250 \mu \mathrm{g}$ of synthetic corticotropin (tetra-cosactide-hexa-acetate, Synacthen, Novartis Pharma, Basel, Switzerland). Blood and salivary samples were taken immediately before and 60 minutes after ACTH injection. The difference between serum cortisol at $60 \mathrm{~min}$ and at baseline (delta cortisol) was calculated to assess the response to ACTH stimulation. A subnormal response to ACTH stimulation was defined by a delta cortisol $<250 \mathrm{nmol} / \mathrm{L}[4]$.

\section{Laboratory analyses}

Salivary cortisol concentrations were determined using an ELISA kit (Enzyme-Linked ImmunoSorbent Assay), obtained from DGR instruments GmbH (Germany). The assay sensitivity was $1 \mathrm{nmol} / \mathrm{L}$. As to specificity, this cortisol assay does not show cross-reaction with cortisone, deoxycorticosterone, 11-deoxycorticortisol, estradiol, testosterone, and 17-hydroxyprogesterone, while it cross-reacts $29 \%$ with corticosterone and $3 \%$ with cortisone. The reference range for our laboratory was 3-40 nmol/L, for both sexes. 
Serum cortisol was measured by chemiluminescent immunometric assay (Immulite 1000, Siemens Medical Solutions Diagnostics, Los Angeles, CA, USA). The detection limit was $5 \mathrm{nmol} / \mathrm{L}$. The reference range was $250-690 \mathrm{nmol} / \mathrm{L}$.

\section{Statistical analyses}

All statistical analyses were performed with STATA statistical software. Categorical data were presented as rates and proportions, continuous data as medians and ranges. Wilcoxon rank-sum test was used for analysis of continuous variables and Chi-Square Test was used for nominal or ordinal explanatory and response variables. P values of less than 0.05 were considered to indicate statistical significance. 


\section{RESULTS}

A total of 71 patients were eligible for inclusion in the study. One patient was excluded because he received a steroid pulse before admission and 15 patients were excluded because the amount of saliva samples was insufficient for the assay (Figure 1).

Baseline characteristics of the 55 evaluated patients are reported in Table 1.

Table 1. Baseline features of the overall samples and the two groups classified according to presence of sepsis.

\begin{tabular}{|c|c|c|c|c|}
\hline Characteristics & $\begin{array}{c}\text { Overall } \\
(n=55)\end{array}$ & $\begin{array}{l}\text { Sepsis } \\
(\mathrm{n}=22)\end{array}$ & $\begin{array}{c}\text { No Sepsis } \\
(n=33)\end{array}$ & $p$ \\
\hline $\begin{array}{l}\text { Gender }- \text { N. }(\%) \\
\text { Male } \\
\text { Female }\end{array}$ & $\begin{array}{l}36(65 \%) \\
19(35 \%)\end{array}$ & $\begin{array}{l}14(63.6 \%) \\
8(36.4 \%)\end{array}$ & $\begin{array}{l}22(66.7 \%) \\
11(33.3 \%)\end{array}$ & 0.86 \\
\hline $\begin{array}{l}\text { Age at admission }-\mathrm{yr} \\
\text { Median [range] }\end{array}$ & 70 [17-87] & 65 [42-87] & 71 [17-84] & 0.49 \\
\hline $\begin{array}{l}\text { BMI }-\mathrm{kg} / \mathrm{m}^{2} \\
\text { Median } \\
\text { [range] }\end{array}$ & $\begin{array}{c}26.8 \\
{[16.3-48.9]}\end{array}$ & $\begin{array}{c}26.0 \\
{[16.3-46.8]}\end{array}$ & $\begin{array}{c}27.5 \\
{[18.5-48.9]}\end{array}$ & 0.10 \\
\hline $\begin{array}{l}\text { Systolic Blood Pressure - } \\
(\mathrm{mmHg}) \\
\text { Median [range] }\end{array}$ & 130 [70-230] & 125 [70-230] & 136 [87-230] & 0.07 \\
\hline $\begin{array}{l}\text { Diastolic Blood Pressure - } \\
(\mathrm{mmHg}) \\
\text { Median [range] }\end{array}$ & 70 [35-130] & 70 [40-130] & 70 [35-120] & 0.47 \\
\hline $\begin{array}{l}\text { Heart rate }-(\mathrm{bpm}) \\
\text { Median [range] }\end{array}$ & 90 [65-160] & 99 [70-130] & 86 [65-160] & 0.32 \\
\hline $\begin{array}{l}\text { Respiratory rate }-(\mathrm{bpm}) \\
\text { Median [range] }\end{array}$ & 26 [12-46] & 24 [12-46] & 27 [14-44] & 0.93 \\
\hline $\begin{array}{l}\mathbf{S O}_{2}-(\%) \\
\text { Median [range] }\end{array}$ & 94 [70-99] & 96 [70-99] & 94 [72-99] & 0.91 \\
\hline $\begin{array}{l}\text { Temperature }-\left({ }^{\circ} \mathrm{C}\right) \\
\text { Median [range] }\end{array}$ & 37 [36-41] & $37.4[36-41]$ & 37 [36-39] & 0.01 \\
\hline $\begin{array}{l}\text { Lactate }-(\mathrm{mmol} / \mathrm{L}) \\
\text { Median [range] }\end{array}$ & $1.4[0.1-8.3]$ & $1.5[0.5-7.7]$ & $1.4[0.1-8.3]$ & 0.80 \\
\hline
\end{tabular}




\begin{tabular}{|l|c|c|c|c|}
\hline $\begin{array}{l}\text { Protein - (g/dL) } \\
\text { Median [range] }\end{array}$ & $6.1[4.3-7.9]$ & $5.5[4.3-7.8]$ & $6.3[5.5-7.1]$ & $\mathbf{0 . 0 2}$ \\
\hline $\begin{array}{l}\text { Albumin - (g/dL) } \\
\text { Median [range] }\end{array}$ & $3.1[0.5-4.3]$ & $2.8[1.5-4.3]$ & $3.4[0.5-4.3]$ & $\mathbf{0 . 0 2}$ \\
\hline $\begin{array}{l}\text { Hospitalization - (day) } \\
\text { Median [range] }\end{array}$ & $11[4-38]$ & $11[4-24]$ & $10.5[4-38]$ & 0.73 \\
\hline $\begin{array}{l}\text { Hospitalization in ED-(day) } \\
\text { Median [range] }\end{array}$ & $6[1-21]$ & $6[2-15]$ & $5[1-10]$ & 0.76 \\
\hline
\end{tabular}

BMI=body mass index; SBP=systolic blood pressure; $\mathrm{DBP}=$ diastolic blood pressure; $\mathrm{SO2}=$ hemoglobin oxygen saturation.

The patient group had different medical emergencies; the most frequent diagnosis at presentation was acute respiratory failure $(50.9 \%)$ followed by acute heart failure $(16.4 \%)$, suspected infections $(16.4 \%)$, trauma $(7.3 \%)$, acute pancreatitis $(3.6 \%)$, septic shock $(3.6 \%)$, or any organ failure (1.8\%). A broad spectrum of comorbidities affected our patients, such as arterial hypertension (56.4\%), diabetes mellitus (30.9\%), coronary artery disease (25.4\%), heart failure (21.8\%), chronic kidney disease (20\%), chronic obstructive pulmonary disease (20\%), arrhythmia (14.5\%), vascular disease $(7.3 \%)$, liver disease $(3.6 \%)$, pulmonary hypertension $(3.6 \%)$, peripheral arterial disease $(1.8 \%)$, peptic ulcer $(1.8 \%)$, autoimmune diseases $(1.8 \%)$. We divided our population in two subgroups based on the presence of sepsis, which was diagnosed in 22 out of 55 patients. Baseline characteristics of the two subgroups of patients are reported in Table 1.

In the overall sample, the median SAPS II score was 37 (16-77), without difference between the two groups (sepsis group, 36, 16-61 vs. no-sepsis group, 37, 17-77, $p=0.76$ ). In the sepsis group, the median qSOFA was 1 [range 0-2].

Median serum cortisol concentration at T0 in the overall sample was $819 \mathrm{nmol} / \mathrm{L}$ (292-2458 $\mathrm{nmol} / \mathrm{L}$ ) and median salivary cortisol concentration at T0 was $41 \mathrm{nmol} / \mathrm{L}$ (range $1-347 \mathrm{nmol} / \mathrm{L}$ ). No patient had baseline serum cortisol $<276 \mathrm{nmol} / \mathrm{L}$. Median serum cortisol concentration at T48 was $634 \mathrm{nmol} / \mathrm{L}(287-1826 \mathrm{nmol} / \mathrm{L})$ and median salivary cortisol concentration at T48 was $13 \mathrm{nmol} / \mathrm{L}$ 
(range 1-253 nmol/L). We found a significant correlation between serum and salivary cortisol concentrations measured at T0 $(r 0.84, p<0.001)$, and T48 $(r 0.81, p<0.001)$.

We found a statistically significant difference between salivary cortisol concentrations at T0 vs. T48 $(p<0.001)$ (Figure 2).

In the sepsis group, salivary cortisol concentration decreased from $60 \mathrm{nmol} / \mathrm{L}$ (range $1-347 \mathrm{nmol} / \mathrm{L}$ ) at T0 to $21 \mathrm{nmol} / \mathrm{L}(1-135 \mathrm{nmol} / \mathrm{L})$ at T48 $(p<0.001)$. In the no-sepsis group, salivary cortisol concentration decreased from $39 \mathrm{nmol} / \mathrm{L}$ (range 1-221 nmol/L) at T0 to $11 \mathrm{nmol}$ (range 1-253 $\mathrm{nmol} / \mathrm{L})$ at T48 ( $p=0.022)$ (Figure 3). We also compared salivary cortisol concentrations between the two groups and we found a statistically significant difference in salivary cortisol values at T48 $(p=0.03)$, while no significant difference was apparent at T0 (Figure 3).

We did not find any significant correlation between serum or salivary cortisol and SAPS values.

For logistic reasons (i.e. night-time admission), the ACTH stimulation test was performed in 33 patients. The serum cortisol value at $60 \mathrm{~min}$ was $1534 \mathrm{nmol} / \mathrm{L}(510-2676 \mathrm{nmol} / \mathrm{L})$, and the salivary cortisol was $156 \mathrm{nmol} / \mathrm{L}$ (range 17-1528 nmol/L); with a significant correlation between them $(r$ 0.49, $p<0.01$ ). The delta serum cortisol was $588 \mathrm{nmol} / \mathrm{L}$ (range $-110-1432 \mathrm{nmol} / \mathrm{L}$ ) and the percentage of the increase was $79 \%$ (range $-6-393 \%$ ). The delta salivary cortisol was $113 \mathrm{nmol} / \mathrm{L}$ (range $-54-1308 \mathrm{nmol} / \mathrm{L}$ ) and the percentage of the increase was 191\% (range $-16-1672 \%$ )

\section{(Figure 4).}

We found a delta serum cortisol $<250 \mathrm{nmol} / \mathrm{L}$ in 4 out 33 cases $(12.1 \%)$. These patients had exceedingly high serum cortisol levels at T0 (1581; 1545; 2458; $1975 \mathrm{nmol} / \mathrm{L}$, respectively), high values of SAPS $(39,58,61,77$, respectively), increased lactate concentrations, and sepsis was diagnosed in three of them. The response of salivary cortisol to Synacthen was also blunted (percent of increment $37 \%,-7 \%,-16 \%, 18 \%$, respectively).

Mortality rate was $1 / 55$ patients at $\mathrm{T} 48$, and $5 / 55$ patients at day 28 . Due to the low mortality rate observed in our cohort, we did not analyze the correlation with cortisol levels. 


\section{DISCUSSION}

In the last 30 years, there was a fierce debate on the existence of a correlation between mortality and cortisol levels in critically ill patients, particularly when levels are at the lower end of the spectrum, configuring the so-called CIRCI $[2,4,5]$, or when they are exceedingly high $[6,7,8]$. In both cases, the assessment of serum cortisol is not completely reliable, due to the decrease of CBG and albumin in critically ill patients [17]. As a matter of fact, $80-90 \%$ of serum cortisol is bound to CBG, $5-10 \%$ is bound to albumin, while only $5 \%$ is unbound [18]. At the same time, the laboratory evaluation of free serum cortisol is difficult, requiring special equipment. On the contrary, salivary cortisol measurement is cheap, noninvasive and unaffected by variations in CBG or albumin.

The recent guidelines on CIRCI diagnosis and management suggest against the use of salivary cortisol for diagnostic purposes, although this is a conditional recommendation with a very low quality of evidence [5]. One of the objections raised in the guidelines concerns the difficulty in collecting adequate salivary samples in critically ill patients, often intubated and dehydrated. Studies report that it was impossible to analyze about $30 \%$ of the salivary samples, due to insufficient saliva, or blood contamination [13,14]; conversely, in one study [12] only 5.5\% of enrolled patients had inadequate saliva samples. In the present study, we confirm that collecting saliva is not an easy task in the ER, since $21.4 \%$ of our patients were excluded due to a small volume of saliva collected. This discrepancy among the studies is probably due to different types of population analyzed, with variable grade of illness severity and number of intubated patients. Whether the use of different saliva-collecting devices (for example infant-swab-devices) could ameliorate the success of obtaining adequate saliva samples in critically ill patients deserves future investigation.

Many studies supported the use of salivary cortisol as a surrogate for free cortisol in patients with critical illness, because it is as reliable as serum free cortisol, but not affected by the high cost and low availability of equilibrium dialysis, needed to determine free serum cortisol [12,13,14].

This concept was confirmed by our study, where we found a significant correlation between serum 
and salivary cortisol measurements. The strong correlation between salivary cortisol and total serum cortisol levels has been demonstrated not only at baseline, as in previous studies $[12,13,14]$ but also after 48 hours of hospitalization. This is a new element introduced by our research reporting a statistically significant difference between T0 and T48 salivary cortisol concentrations in the whole group, and in the two subgroups of septic and non-septic patients. We showed that salivary cortisol decreases after 48 hours, a finding that likely reflects the shutting down of adrenal hyperactivity. Interestingly, the change in salivary cortisol seems to be more sensitive and precocious that serum cortisol, which was less modified over time. We observed a similar pattern during ACTH stimulation test. There are scanty data on the response of salivary cortisol to Synacthen and a universally accepted cut-off is not available $[12,19,20]$, due to the great heterogeneity of the assays used to measure salivary cortisol between different studies.

This is the first study with a direct comparison between septic and non-septic patients, classified on the basis of the recent diagnostic criteria of sepsis [16]. In our study, we did not find any correlation between the severity of illness and salivary or serum cortisol levels. Therefore, our data do not seem to support the hypothesis that salivary cortisol increases in parallel to the severity of stress [13]. However, we may disclose the fact that the severity of illness and sepsis was moderate in many patients. Moreover, we found a significantly higher value of salivary cortisol at T48 in the group of septic patients, which may reflect a more persistent activation of the HPA axis in this condition. We also found a correlation between serum and salivary cortisol at 60 min of the ACTH stimulation test. The role of salivary cortisol as surrogate for serum free cortisol in dynamic testing of adrenocortical function has been previously investigated [12, 19, 20], and our findings further support the use of salivary cortisol in this setting.

We did not find any evidence of CIRCI in our cohort, since no patient had baseline serum cortisol $<276 \mathrm{nmol} / \mathrm{L}$, and a delta serum cortisol $<250 \mathrm{nmol} / \mathrm{L}$ after ACTH stimulation was observed in only $12 \%$ of cases. However, baseline cortisol levels were very high in such patients, suggesting that the reduced delta cortisol value may reflect a maximally stimulated HPA axis more than 
adrenal insufficiency. Interestingly, the 4 patients with a delta serum cortisol $<250 \mathrm{nmol} / \mathrm{L}$ after ACTH stimulation had concomitantly blunted salivary cortisol response.

We acknowledge the limitations of the study, including a small sample size and the heterogeneity of the population. Moreover, it could be argued that the low severity of illness in our patients, confirmed by a low mortality rate, is also a limitation.

To conclude, proven that patients are able to collaborate and provide adequate saliva samples, salivary cortisol may be used to check the degree of stress-induced activation of the HPA axis, and appears as a suitable tool for multiple measurements over time.

\section{Declaration of Interest:}

The authors have stated explicitly that there are no conflicts of interest in connection with this article.

Funding: This research did not receive any specific grant from any funding agency in the public, commercial or not-for-profit sector.

Acknowledgements: We wish to thank Laura Saba for assistance with lab assays. 


\section{REFERENCES}

(1) Chrousos, G. P. Stress and Disorders of the Stress System. Nature Reviews Endocrinology 2009, 5 (7), 374-381. https://doi.org/10.1038/nrendo.2009.106.

(2) Annane, D.; Sébille, V.; Troché, G.; Raphaël, J. C.; Gajdos, P.; Bellissant, E. A 3-Level Prognostic Classification in Septic Shock Based on Cortisol Levels and Cortisol Response to Corticotropin. JAMA : the journal of the American Medical Association 2000, 283 (8), 1038-1045. https://doi.org/10.1001/jama.283.8.1038.

(3) Schroeder, S.; Wichers, M.; Klingmüller, D.; Höfer, M.; Lehmann, L. E.; von Spiegel, T.; Hering, R.; Putensen, C.; Hoeft, A.; Stüber, F. The Hypothalamic-Pituitary-Adrenal Axis of Patients with Severe Sepsis: Altered Response to Corticotropin-Releasing Hormone. Critical care medicine 2001, 29 (2), 310-316.

(4) Marik, P. E.; Pastores, S. M.; Annane, D.; Meduri, G. U.; Sprung, C. L.; Arlt, W.; Keh, D.; Briegel, J.; Beishuizen, A.; Dimopoulou, I.; et al. Recommendations for the Diagnosis and Management of Corticosteroid Insufficiency in Critically III Adult Patients: Consensus Statements from an International Task Force by the American College of Critical Care Medicine. Crit Care Med 2008, 36 (6), 1937-1949. https://doi.org/10.1097/CCM.0b013e31817603ba.

(5) Annane, D.; Pastores, S. M.; Rochwerg, B.; Arlt, W.; Balk, R. A.; Beishuizen, A.; Briegel, J.; Carcillo, J.; Christ-Crain, M.; Cooper, M. S.; et al. Guidelines for the Diagnosis and Management of Critical Illness-Related Corticosteroid Insufficiency (CIRCI) in Critically III Patients (Part I): Society of Critical Care Medicine (SCCM) and European Society of Intensive Care Medicine (ESICM) 2017. Critical care medicine 2017, 45 (12), 2078-2088. https://doi.org/10.1097/CCM.0000000000002737.

(6) Tarjanyi, Z.; Montsko, G.; Kenyeres, P.; Marton, Z.; Hagendorn, R.; Gulyas, E.; Nemes, O.; Bajnok, L.; G, L. K.; Mezosi, E. Free and Total Cortisol Levels Are Useful Prognostic Markers in Critically III Patients: A Prospective Observational Study; 2014; Vol. 171. https://doi.org/10.1530/EJE-14-0576.

(7) Levy-Shraga, Y.; Pinhas-Hamiel, O.; Molina-Hazan, V.; Tamir-Hostovsky, L.; Eini, Z. M.; Lerner-Geva, L.; Paret, G. Elevated Baseline Cortisol Levels Are Predictive of Bad Outcomes in Critically III Children. Pediatric emergency care 2018, 34 (9), 613-617. https://doi.org/10.1097/PEC.0000000000000784.

(8) Pandya, U.; Polite, N.; Wood, T.; Lieber, M. Increased Total Serum Random Cortisol Levels Predict Mortality in Critically III Trauma Patients.

(9) Arafah, B. M. Hypothalamic Pituitary Adrenal Function during Critical Illness: Limitations of Current Assessment Methods. The Journal of clinical endocrinology and metabolism 2006, 91 (10), 37253745. https://doi.org/10.1210/jc.2006-0674.

(10) Gozansky, W. S.; Lynn, J. S.; Laudenslager, M. L.; Kohrt, W. M. Salivary Cortisol Determined by Enzyme Immunoassay is Preferable to Serum Total Cortisol for Assessment of Dynamic Hypothalamic-Pituitary-Adrenal Axis Activity. Clinical Endocrinology 2005, 63 (3), 336-341. https://doi.org/10.1111/j.1365-2265.2005.02349.x.

(11) Raff, H. Utility of Salivary Cortisol Measurements in Cushing's Syndrome and Adrenal Insufficiency. Journal of Clinical Endocrinology and Metabolism 2009, 94 (10), 3647-3655. https://doi.org/10.1210/jc.2009-1166.

(12) Arafah, B. M.; Nishiyama, F. J.; Tlaygeh, H.; Hejal, R. Measurement of Salivary Cortisol Concentration in the Assessment of Adrenal Function in Critically III Subjects: A Surrogate Marker of the Circulating Free Cortisol. Journal of Clinical Endocrinology and Metabolism 2007, 92 (8), 2965-2971. https://doi.org/10.1210/jc.2007-0181.

(13) Carvalho, R.; De Mello, V.; Sad, E. F.; Andrade, B. C.; Pretti, S.; Neves, F.; Maria, S.; Santos, E.; Maria, M.; Sarquis, S.; et al. Serum and Salivary Cortisol in the Diagnosis of Adrenal Insufficiency and as a Predictor of the Outcome in Patients with Severe Sepsis. Arq Bras Endocrinol Metab 2011, 5555 (77), 455-459. https://doi.org/10.1590/S0004-27302011000700004.

(14) Estrada-Y-Martin, R. M.; Orlander, P. R. Salivary Cortisol Can Replace Free Serum Cortisol Measurements in Patients with Septic Shock. Chest 2011, 140 (5), 1216-1222. https://doi.org/10.1378/chest.11-0448. 
(15) Singer, M.; Deutschman, C. S.; Seymour, C. W.; Shankar-Hari, M.; Annane, D.; Bauer, M.; Bellomo, R.; Bernard, G. R.; Chiche, J.-D.; Coopersmith, C. M.; et al. The Third International Consensus Definitions for Sepsis and Septic Shock (Sepsis-3). Jama 2016, 315 (8), 801-810.

https://doi.org/10.1001/jama.2016.0287.

(16) Le Gall, J.-R.; Lemeshow, S.; Saulnier, F. A New Simplified Acute Physiology Score (SAPS II) Based on a European/North American Multicenter Study. JAMA: The Journal of the American Medical Association 1993, 270 (24), 2957. https://doi.org/10.1001/jama.1993.03510240069035.

(17) Beishuizen, A.; Thijs, L. G.; Vermes, I. Patterns of Corticosteroid-Binding Globulin and the Free Cortisol Index during Septic Shock and Multitrauma. Intensive Care Medicine 2001, 27 (10), 15841591. https://doi.org/10.1007/s001340101073.

(18) Hammond, G. L.; Smith, C. L.; Underhill, D. A. Molecular Studies of Corticosteroid Binding Globulin Structure, Biosynthesis and Function. The Journal of Steroid Biochemistry and Molecular Biology 1991, 40 (4-6), 755-762. https://doi.org/10.1016/0960-0760(91)90300-T.

(19) Raff, H.; Biru, N.; Reisinger, N., Kramer, D.J. Dissociation of ACTH and cortisol in septic and nonseptic ICU patients. Endocrine. 2017, 55 (1), 307-310. https://doi.org/10.1007/s12020 016-1034-2.

(20) Raff, H.; Brock, S.; Findling, JW. Cosyntropin-stimulated salivary cortisol in hospitalized patients with hypoproteinemia. Endocrine. 2008, 34 (1-3), 68-74. https://doi.org/10.1007/s12020-008-9101-y. 
Figure 1. Study cohort.

71 patients

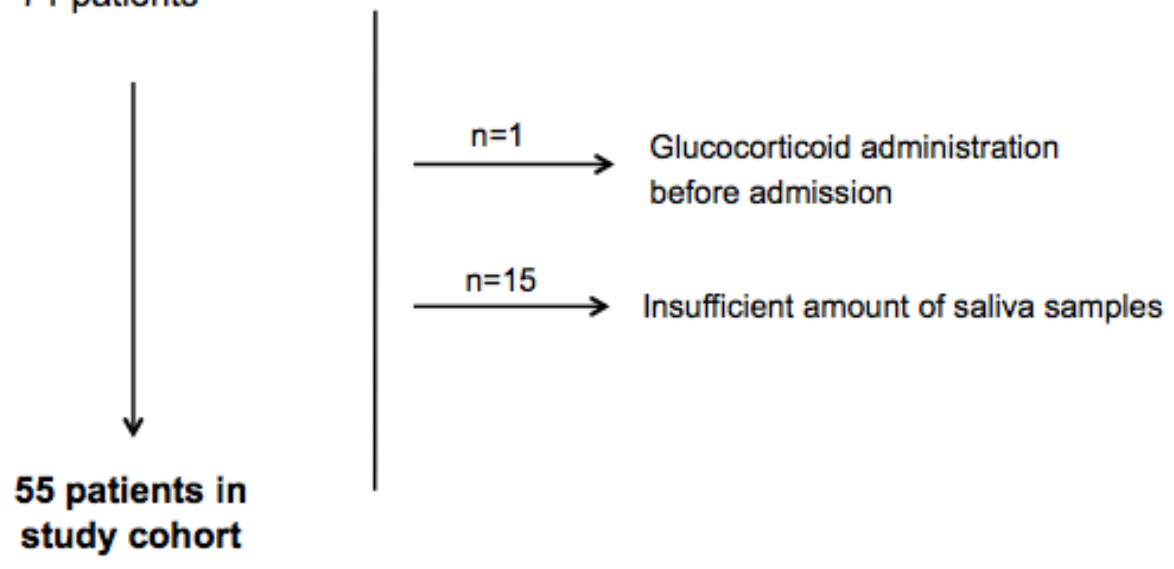

Figure 2. Salivary (2a) and serum (2b) cortisol concentration in the overall sample at T0 and T48.

The box identifies $25-75 \%$ range and the whisker the non-outlier range.
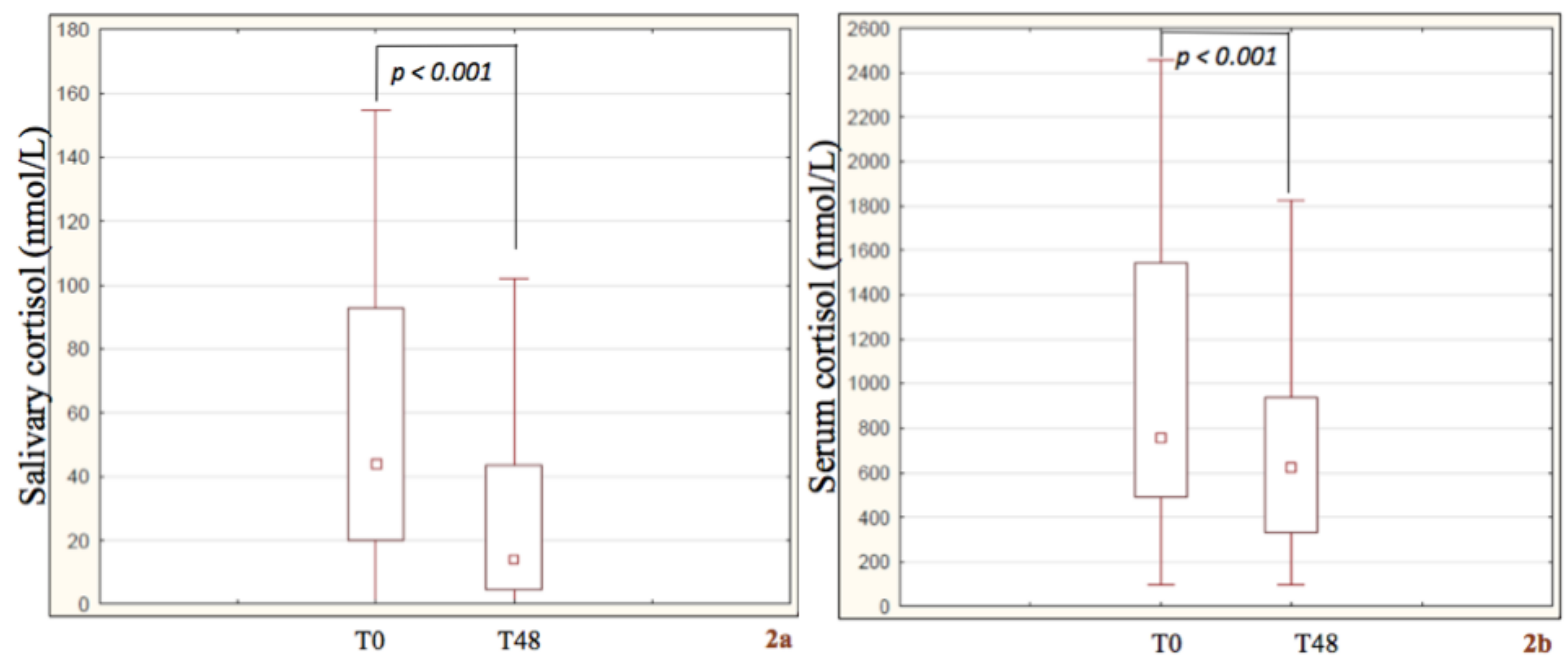
Figure 3. Salivary (3a) and serum (3b) cortisol concentration at T0 and T48, in sepsis and no sepsis group.

The box identifies the 25-75\% range and the whisker the non-outlier range.
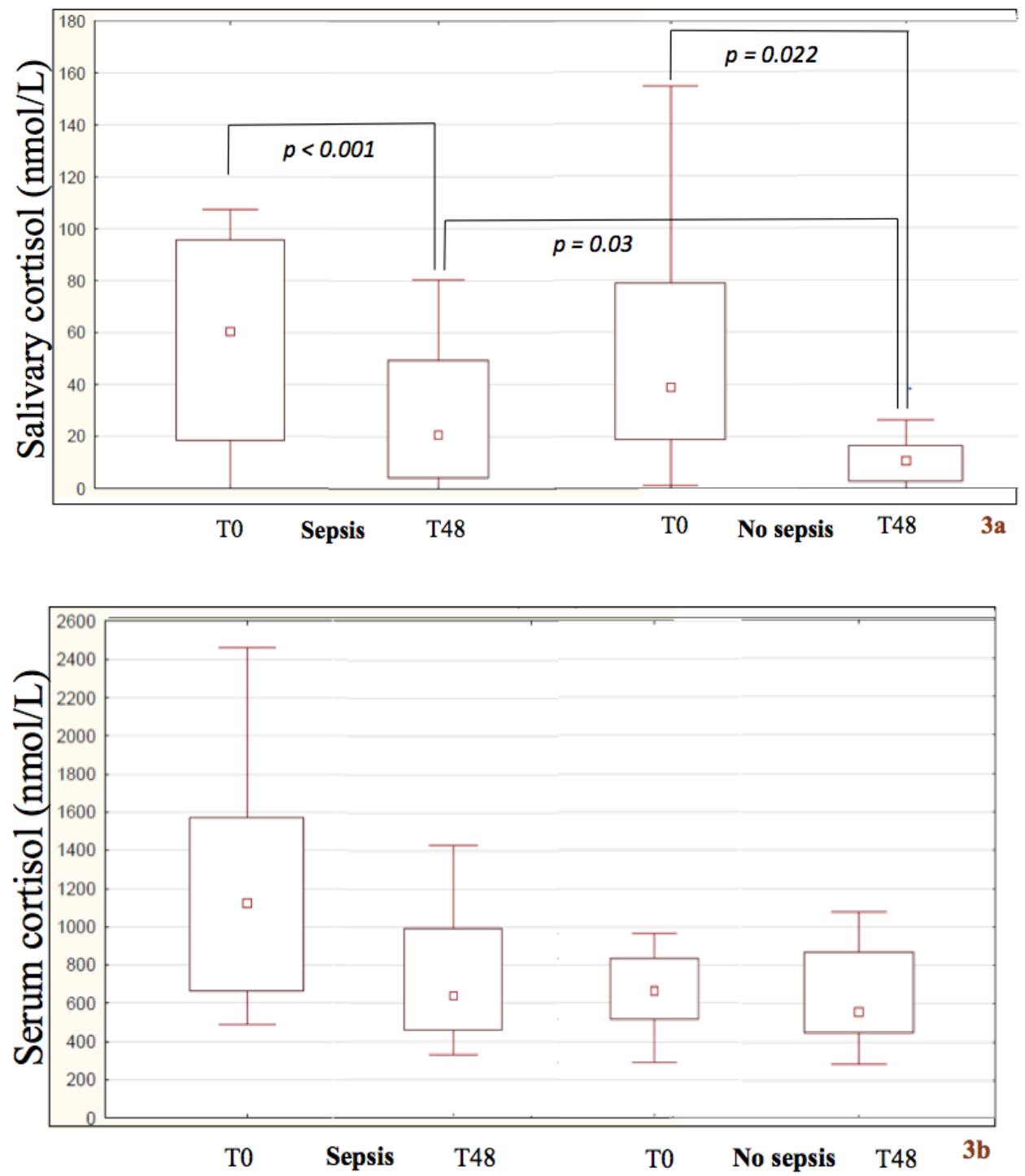
Figure 4. Salivary (4a) and serum cortisol (4b) before and after ACTH stimulation test.

The box identifies the $25-75 \%$ range and the whisker the non-outlier range.
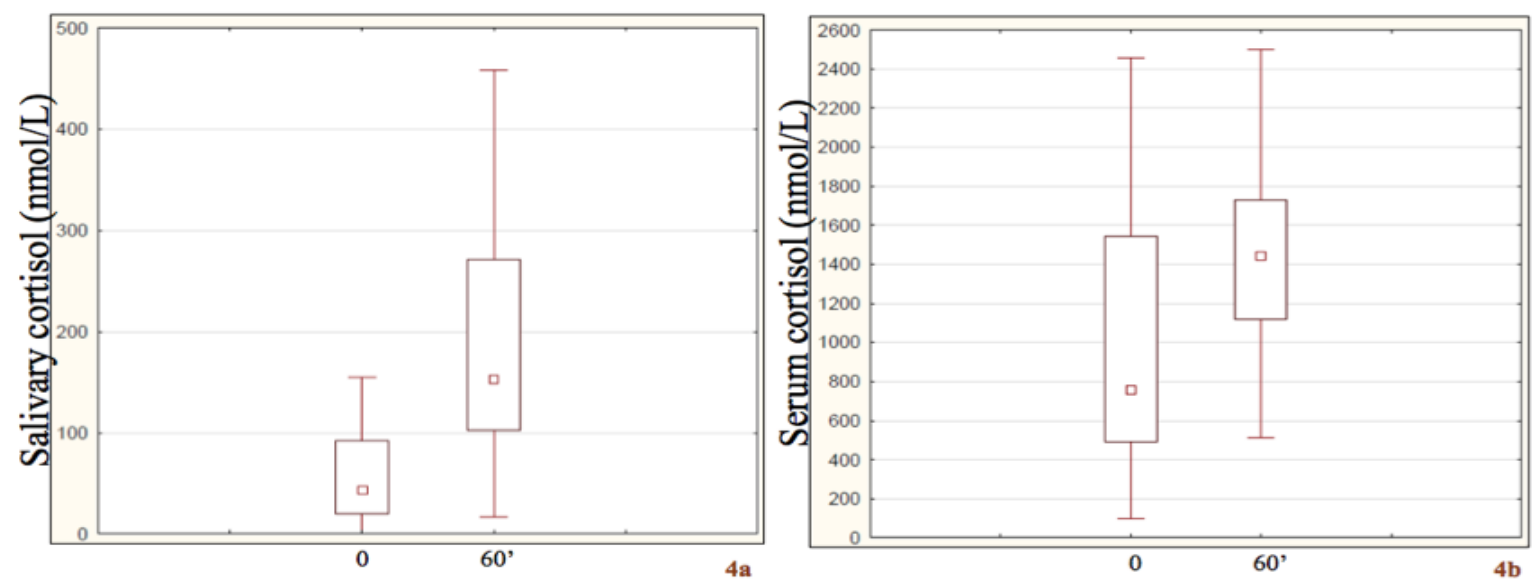
We wish fo contirn that here are no known conllicts of interest associated with this publication and there has been no signilicant financial supmort for this work that couk have influenced its nutcome.

We contirm that the manuscript has been read and appreved by all named authors and that there are no other persons who satislied the criteria for authorship but are not listed. We funber confinn that the order of authors listed in the manuserpt has been approved by all of us.

We conthrn that we have ghen due consideraion to the protection of intellectual property associated with this work and hat there are no inpediments publication induding the timing of pubtication, wh thespecto intellectual property ln so doing we confinm that we have followed the regulations of our institutions concening intellectual property

Wounderstand that he Corresponding Author is live sole contact for the Editorial process Gincluding Editorial Manager and direct communications with the office). She is responsibfe for comminatcating with we other authors about progress, submissions of revisions and fral approvil of proofs. We confurm that we have provided a current correct cmail address which is access ble by he cortesponding duthrand which has ben conligured to acceptemall rom tropean joumal of Intemal Nediche.

signed by all aullors s follows

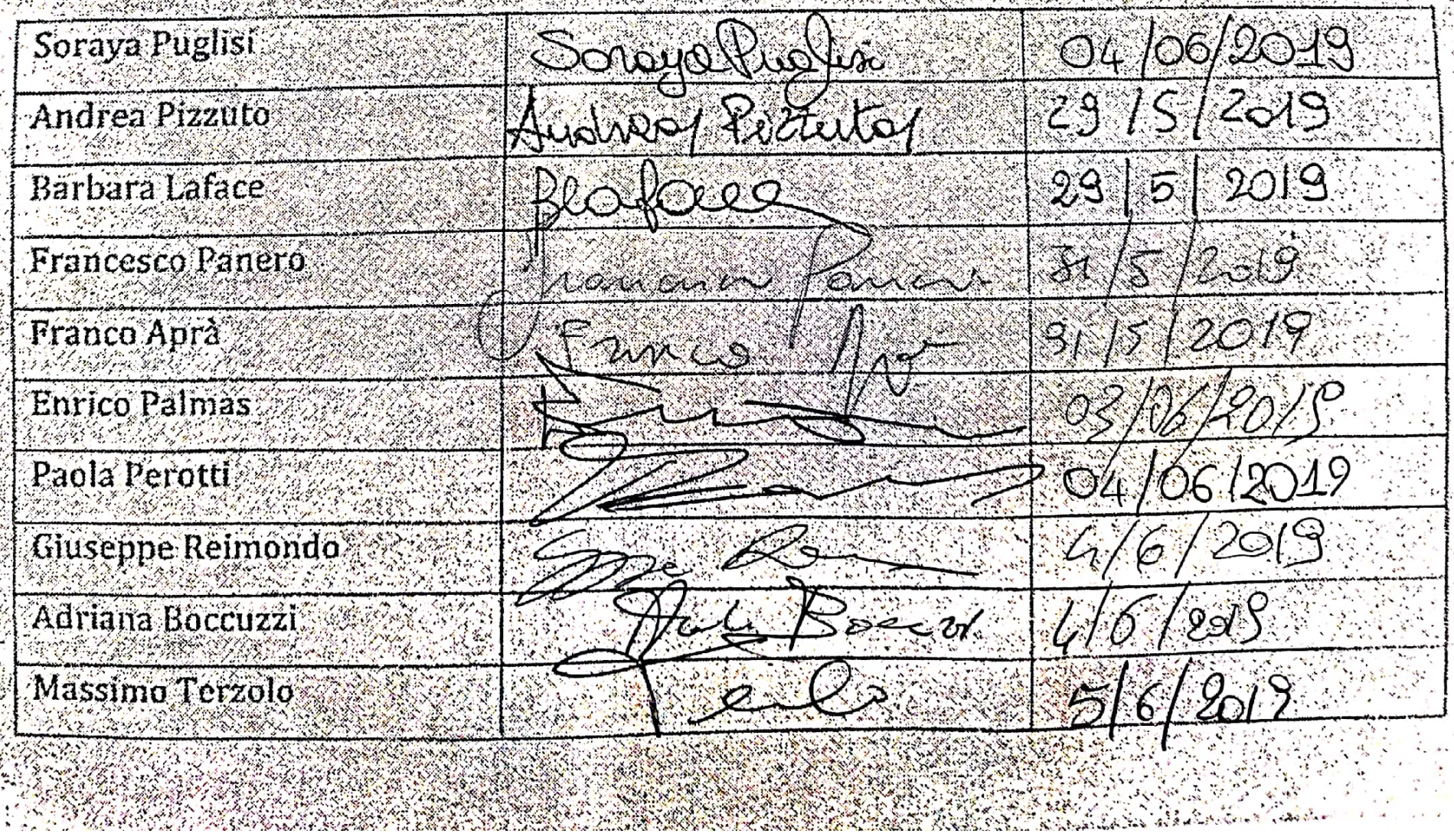




\section{HIGHLIGHTS}

- The usefulness of salivary cortisol to study stress-related adrenal response is still debated.

- Fifty-five critically ill patients were studied at baseline (T0) and after 48 hours (T48).

- A significant correlation between serum and salivary cortisol at T0 and T48 was found.

- Salivary cortisol decreases at T48, reflecting the shutting down of adrenal hyperactivity.

- Salivary cortisol appears a suitable tool for multiple measurements over time. 